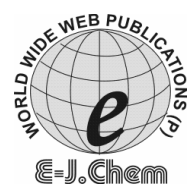

http://www.e-journals.net
ISSN: 0973-4945; CODEN ECJHAO

E-Journal of Chemistry

Vol. 5, No.3, pp. 467-472, July 2008

\title{
Green Synthesis of Benzylated Aromatics Using Iron Loaded Mesoporous Materials
}

\author{
MUTHURAJ ESTHER LEENA PREETHI, SHANMUGAM \\ REVATHI and THIRIPURANTHAGAN SIVAKUMAR* \\ Catalysis Laboratory, Department of Chemical Engineering,
}

A. C. College of Technology, Anna University, Chennai - 600025 . India.

sivakumar@annauniv.edu; Tel: + 91-44-22203529, +919444159636

Received 30 October 2007; Accepted 20 December 2007

\begin{abstract}
Syntheses of benzylated aromatics like diphenylmethane and its derivatives by the condensation of benzene or toluene or $o$-xylene with benzylchloride or 4-methylbenzylchloride in the presence of a catalytic amount of various iron loaded mesoporous solid acid catalysts such as Fe/Al-MCM-41 $(\mathrm{Si} / \mathrm{Al}=25), \mathrm{Fe} / \mathrm{Al}-\mathrm{MCM}-41(\mathrm{Si} / \mathrm{Al}=50)$ and $\mathrm{Fe} / \mathrm{Al}-\mathrm{MCM}-41(\mathrm{Si} / \mathrm{Al}=100)$ are reported.
\end{abstract}

Keywords: Green synthesis, Al-MCM-41, Benzylation, Mesoporous materials, Iron

\section{Introduction}

The synthesis of M41S family of siliceous solids with sharply distributed pore diameter in the range of 20-100 $\AA$ have achieved the main goals in heterogeneous catalysis over the past two decades since it possessed the crystallinity and well-defined structure of zeolites in the mesoporous range ${ }^{1-4}$ Iron loaded MCM-41 materials are remarkable for their molecular and electronic diversity and have quite significance in many areas e.g. catalysis, medicine, material science etc.

These iron loaded MCM-41 materials have received much attention because of their redox properties and unusual activity in alkylation and oxidation reactions ${ }^{5-7}$ which is higher compared to conventional mineral acids ${ }^{8}$. Lewis acids ${ }^{9}$, ion exchange resins ${ }^{10}$, mixed oxides ${ }^{11}$ and iron supported zeolites, clay catalysts ${ }^{12,13}$. The use of iron loaded mesoporous materials as catalyst can also eliminate the hurdles like pore size constraint, recyclability, thermal and hydrothermal stability etc. posed by other support materials. In the past, benzylation of benzene has been carried over different iron containing mesoporous materials like Fe containing mesoporous silicate catalysts ${ }^{14}$ and FeSBA- $15^{15}$ but so far no such work has been carried out over Fe/Al-MCM-41. Introduction of iron into the mesoporous material by wet impregnation technique showed high redox property 
than tetrahedrally coordinated $\mathrm{Fe}^{3+}$ located in the skeleton of the materials ${ }^{16}$ which would be highly beneficial for the title reaction as it follows redox mechanism as confirmed by earlier report ${ }^{14}$. Iron loaded Al-MCM-41 catalyst prepared by wet impregnation was found to be the most effective catalyst in the sulfurisation of methanol involving redox mechanism than iron impregnated purely siliceous MCM- $41^{17}$.

Aromatic benzylation is a synthetically important transformation for the preparation of wide variety of benzyl aromatics, which are key intermediates in the multifaceted angle of industrial applications. Diphenylmethane and its derivatives are widely used as pharmaceuticals, petrochemicals, cosmetics, dyes, fine chemicals, insulators etc ${ }^{18}$., Mesoporous materials as support ${ }^{19}$ and iron loaded mesoporous materials ${ }^{20}$ as catalysts have proved to be highly active and efficient in our previous studies.

We report the results of synthesis of benzyl aromatics by using benzylchloride and substituted benzylchloride over this three different types of catalytic amounts of iron loaded MCM-41 like Fe/Al-MCM-41; Si/Al=25, Fe/Al-MCM-41; Si/Al=50 and Fe/Al-MCM-41; $\mathrm{Si} / \mathrm{Al}=100$ (Scheme 1). The effects of reaction parameter such as temperature and reaction times on reaction yields are also studied and the results are briefly discussed.



Scheme 1.

Compound $\mathrm{I}$ is Benzene if $\mathrm{R}_{1}, \mathrm{R}_{2}$ and $\mathrm{R}_{3}=\mathrm{H}$ or Toluene if $\mathrm{R}_{1}, \mathrm{R}_{2}=\mathrm{H}$ and $\mathrm{R}_{3}=\mathrm{CH}_{3}$ or Xylene if $\mathrm{R}_{1}=\mathrm{H}, \mathrm{R}_{2}$ and $\mathrm{R}_{3}=\mathrm{CH}_{3}$.

Compound II is Benzyl chloride if $\mathrm{R}_{4}=\mathrm{C}_{6} \mathrm{H}_{5}$ or 4-methylbenzyl chloride if $\mathrm{R}_{4}=p-\mathrm{CH}_{3} \mathrm{C}_{6} \mathrm{H}_{4}$ Compound III is Diphenylmethane if $\mathrm{R}_{1}, \mathrm{R}_{2}, \mathrm{R}_{3}=\mathrm{H}, \mathrm{R}_{4}=\mathrm{C}_{6} \mathrm{H}_{5}$ or 1-benzyl-4-methylbenzene if $\mathrm{R}_{1}=\mathrm{CH}_{3}, \mathrm{R}_{2}, \mathrm{R}_{3}=\mathrm{H}, \mathrm{R}_{4}=\mathrm{C}_{6} \mathrm{H}_{5}$ or if $\mathrm{R}_{1}, \mathrm{R}_{2}, \mathrm{R}_{3}=\mathrm{H}, \mathrm{R}_{4}=p-\mathrm{CH}_{3} \mathrm{C}_{6} \mathrm{H}_{4}$ or ditolylmethane if $\mathrm{R}_{1}=\mathrm{CH}_{3}, \mathrm{R}_{2}, \mathrm{R}_{3}=\mathrm{H}, \mathrm{R}_{4}=p-\mathrm{CH}_{3} \mathrm{C}_{6} \mathrm{H}_{4}$ or 4-benzyl-1,2-dimethylbenzene if $\mathrm{R}_{1}, \mathrm{R}_{2}=\mathrm{CH}_{3}, \mathrm{R}_{3}=\mathrm{H}, \mathrm{R}_{4}=\mathrm{C}_{6} \mathrm{H}_{5}$ or 3,4-dimethylphenyltolylmethane if $\mathrm{R}_{1}, \mathrm{R}_{2}=\mathrm{CH}_{3}, \mathrm{R}_{3}=\mathrm{H}$, $\mathrm{R}_{4}=p-\mathrm{CH}_{3} \mathrm{C}_{6} \mathrm{H}_{4}$

\section{Experimental}

\section{General}

All chemicals were obtained from Merck and used as received. Fe/Al-MCM-41 $(\mathrm{Si} / \mathrm{Al}=25), \mathrm{Fe} / \mathrm{Al}-\mathrm{MCM}-41(\mathrm{Si} / \mathrm{Al}=50)$ and $\mathrm{Fe} / \mathrm{Al}-\mathrm{MCM}-41(\mathrm{Si} / \mathrm{Al}=100)$ were prepared according to the literature ${ }^{16}$. The synthesis procedure and characterisation of the catalyst used are discussed in detail in our previous report ${ }^{20}$. GC-MS analyses were performed on Shimadzu GC-MS-QP 5000 with a PE-5 capillary column; scan mode 40-400 amu. IR spectra were obtained with a Buck Scientific 500 spectrometer. ${ }^{1} \mathrm{H}-\mathrm{NMR}$ spectra were recorded on a Bruker $90 \mathrm{MHz}$ FT-NMR.

Benzene $(146.7 \mathrm{mmol})$ and benzylchloride $(9.0 \mathrm{mmol})$ were taken in a $50 \mathrm{~mL} \mathrm{RB}$ flask followed by catalyst $(0.1 \mathrm{~g})$. The reaction mixture was heated at reflux temperature $\left(80^{\circ} \mathrm{C}\right.$ for $4 \mathrm{~h}$.). The products were analyzed using gas chromatograph (Shimadzu model GC17A) equipped with flame ionization detector fitted with OV-101 column ( $2 \mathrm{~m}$ length). After completion of the reaction, 
the catalyst was filtered off and dried. The quantity of Toluene (122.4 mmol), xylene (106.5mmol) and 4-methylbenzylchloride $(7.5 \mathrm{mmol})$ were used in the respective reactions. All products were identified by comparison of their spectroscopic data with the data of the authentic samples.

Spectral data for selected samples

Diphenylmethane

${ }^{1} \mathrm{H}-\mathrm{NMR}$ (CDCl3): 7.06-7.14 (m, $\left.10 \mathrm{H}, \mathrm{Ar}-\mathrm{H}\right), 3.81$ (s, 2H, $\mathrm{CH}_{2}$ ). MS: m/z $167\left[\mathrm{M}^{+}\right]$.

Ditolylmethane

${ }^{1} \mathrm{H}-\mathrm{NMR}(\mathrm{CDCl} 3): 6.94(\mathrm{~d}, 4 \mathrm{H}, \mathrm{Ar}-\mathrm{H}), 6.89$ (d, 4H, Ar-H), $3.81\left(\mathrm{~s}, 2 \mathrm{H}, \mathrm{CH}_{2}\right), 2.35$ (s, 6H, $\left.\mathrm{CH}_{3}\right)$. MS: $m / 2,197\left[\mathrm{M}^{+}\right]$.

1-Benzyl-4-methylbenzene

${ }^{1} \mathrm{H}-\mathrm{NMR}$ (CDCl3): 6.94-7.14(m, 9H, Ar-H), 3.81 (s, 2H,CH ), 2.35 (s, 3H, $\mathrm{CH}_{3}$ ). MS: m/z $182\left[\mathrm{M}^{+}\right]$.

4-Benzyl-1,2-dimethylbenzene

${ }^{1} \mathrm{H}-\mathrm{NMR}$ (CDCl3): 6.74-7.14(m, 8H, Ar-H) , 3.81 ( s, 2H, $\mathrm{CH}_{2}$ ), 2.35 (s, 6H, $\mathrm{CH}_{3}$ ). MS: $m / z 197$ [M+].

\section{3,4-Dimethylphenyltolylmethane}

${ }^{1} \mathrm{H}-\mathrm{NMR}(\mathrm{CDCl} 3)$ : 6.74-7.94(m, 7H, Ar-H), 3.81 (s, 2H,CH$), 2.35$ (s, 9H, $\mathrm{CH}_{3}$ ). MS: $m / z 212\left[\mathrm{M}^{+}\right]$.

\section{Results and Discussion}

At the onset, benzylation of benzene with benzylchloride was studied over all synthesized catalysts Fe/Al-MCM-41; Si/Al=25, Fe/Al-MCM-41; Si/Al=50 and Fe/Al-MCM-41; $\mathrm{Si} / \mathrm{Al}=100$. The products obtained are diphenylmethane (DPM) and the isomers of dibenzylbenzene (DBB) such as 1,2-DBB and 1,4-DBB. The results indicate that the nature of the catalyst plays an important role on their catalyticactivities. As shown in Table1, Fe/AlMCM-41 (25) showed the highest activity and gave better yields. Although iron loading was found to be the same (10 wt. \%) in all the synthesized catalysts higher conversion obtained over Fe/Al-MCM-41 (25) catalysts may be due to the high acidity of this catalyst ${ }^{20}$. The selectivity towards diphenylmethane was high over Fe/Al-MCM-41 (25) catalyst.

The effect of time on stream on the percentage of yields was studied and the results are given in Table 2 at all the temperatures for all the catalysts. The results indicated the increase in the yield increased with the reaction time. The percentage yield was found to be $100 \%$ at $80^{\circ} \mathrm{C}$ and $110^{\circ} \mathrm{C}$ with comparatively highly acidic Fe/Al-MCM-41 (25) catalyst in the benzylation of benzene and $100 \%$ yield was obtained in the benzylation of toluene at $80^{\circ} \mathrm{C}$ and $110^{\circ} \mathrm{C}$ with Fe/Al-MCM-41 catalyst with Si /Al ratio 25 and 50.

Table 1. Catalytic activity of various catalysts in the benzylation of benzene with benzylchloride

\begin{tabular}{|c|c|c|c|c|c|}
\hline \multirow{3}{*}{ S.No. } & \multirow{3}{*}{ Catalyst } & \multirow{3}{*}{ Total Conversion, $\%$} & \multicolumn{3}{|c|}{ Selectivity, \% } \\
\hline & & & \multirow[t]{2}{*}{ DPM } & \multicolumn{2}{|c|}{ Isomers of DBB } \\
\hline & & & & 1,2-DBB & 1,4-DBB \\
\hline 1 & $\mathrm{Fe} / \mathrm{Al}-\mathrm{MCM}-41^{\mathrm{a}}$ & 100 & 93 & 7 & - \\
\hline 2 & $\mathrm{Fe} / \mathrm{Al}-\mathrm{MCM}-41^{\mathrm{b}}$ & 98 & 95 & 3 & - \\
\hline 3 & $\mathrm{Fe} / \mathrm{Al}-\mathrm{MCM}-41^{\mathrm{c}}$ & 78 & 70 & 6 & 2 \\
\hline
\end{tabular}

*Reaction conditions: Catalyst $=0.1 \mathrm{~g}$; Temperature $: 80{ }^{\circ} \mathrm{C} ;{ }^{\mathrm{a}} \mathrm{Si} / \mathrm{Al}=25 ;{ }^{\mathrm{b}} \mathrm{Si} / \mathrm{Al}=50 ;{ }^{\mathrm{c}} \mathrm{Si} / \mathrm{Al}=100$ 
Table 2. Effect of temperature on the \% yield of dibenzyl derivatives over various iron loaded catalysts

\begin{tabular}{|c|c|c|c|c|c|}
\hline \multirow{2}{*}{ S.No. } & \multirow{2}{*}{ Catalyst } & \multirow{2}{*}{ Time, $\mathrm{h}$} & \multicolumn{3}{|c|}{ Yield, $\%^{a}$} \\
\hline & & & $50^{\circ} \mathrm{C}$ & $80^{\circ} \mathrm{C}$ & $110^{\circ} \mathrm{C}$ \\
\hline 1 & $\mathrm{Fe} / \mathrm{Al}-\mathrm{MCM}-41^{\mathrm{a}}$ & 0.5 & 68 & 73 & 78 \\
\hline 2 & $\mathrm{Fe} / \mathrm{Al}-\mathrm{MCM}-41^{\mathrm{a}}$ & 1 & 77 & 81 & 85 \\
\hline 3 & $\mathrm{Fe} / \mathrm{Al}-\mathrm{MCM}-41^{\mathrm{a}}$ & 2 & 84 & 89 & 93 \\
\hline 4 & $\mathrm{Fe} / \mathrm{Al}-\mathrm{MCM}-41^{\mathrm{a}}$ & 3 & 89 & 97 & 98 \\
\hline 5 & $\mathrm{Fe} / \mathrm{Al}-\mathrm{MCM}-41^{\mathrm{a}}$ & 4 & 95 & 100 & 100 \\
\hline 6 & $\mathrm{Fe} / \mathrm{Al}-\mathrm{MCM}-41^{\mathrm{b}}$ & 0.5 & 63 & 67 & 69 \\
\hline 7 & $\mathrm{Fe} / \mathrm{Al}-\mathrm{MCM}-41^{\mathrm{b}}$ & 1 & 69 & 73 & 77 \\
\hline 8 & $\mathrm{Fe} / \mathrm{Al}-\mathrm{MCM}-41^{\mathrm{b}}$ & 2 & 73 & 78 & 82 \\
\hline 9 & $\mathrm{Fe} / \mathrm{Al}-\mathrm{MCM}-41^{\mathrm{b}}$ & 3 & 86 & 89 & 93 \\
\hline 10 & $\mathrm{Fe} / \mathrm{Al}-\mathrm{MCM}-41^{\mathrm{b}}$ & 4 & 93 & 98 & 99 \\
\hline 11 & $\mathrm{Fe} / \mathrm{Al}-\mathrm{MCM}-41^{\mathrm{c}}$ & 0.5 & 42 & 45 & 52 \\
\hline 12 & $\mathrm{Fe} / \mathrm{Al}-\mathrm{MCM}-41^{\mathrm{c}}$ & 1 & 51 & 56 & 58 \\
\hline 13 & $\mathrm{Fe} / \mathrm{Al}-\mathrm{MCM}-41^{\mathrm{c}}$ & 2 & 57 & 61 & 66 \\
\hline 14 & $\mathrm{Fe} / \mathrm{Al}-\mathrm{MCM}-41^{\mathrm{c}}$ & 3 & 65 & 72 & 75 \\
\hline 15 & $\mathrm{Fe} / \mathrm{Al}-\mathrm{MCM}-41^{\mathrm{c}}$ & 4 & 74 & 78 & 81 \\
\hline 16 & $\mathrm{Fe} / \mathrm{Al}-\mathrm{MCM}-41^{\mathrm{a}}$ & 0.5 & 59 & 62 & 68 \\
\hline 17 & $\mathrm{Fe} / \mathrm{Al}-\mathrm{MCM}-41^{\mathrm{a}}$ & 1 & 68 & 72 & 78 \\
\hline 18 & $\mathrm{Fe} / \mathrm{Al}-\mathrm{MCM}-41^{\mathrm{a}}$ & 2 & 75 & 79 & 84 \\
\hline 19 & $\mathrm{Fe} / \mathrm{Al}-\mathrm{MCM}-41^{\mathrm{a}}$ & 3 & 84 & 89 & 90 \\
\hline 20 & $\mathrm{Fe} / \mathrm{Al}-\mathrm{MCM}-41^{\mathrm{a}}$ & 4 & 89 & 100 & 100 \\
\hline 21 & $\mathrm{Fe} / \mathrm{Al}-\mathrm{MCM}-41^{\mathrm{b}}$ & 0.5 & 62 & 70 & 76 \\
\hline 22 & $\mathrm{Fe} / \mathrm{Al}-\mathrm{MCM}-41^{\mathrm{b}}$ & 1 & 69 & 75 & 80 \\
\hline 23 & $\mathrm{Fe} / \mathrm{Al}-\mathrm{MCM}-41^{\mathrm{b}}$ & 2 & 75 & 81 & 88 \\
\hline 24 & $\mathrm{Fe} / \mathrm{Al}-\mathrm{MCM}-41^{\mathrm{b}}$ & 3 & 89 & 91 & 93 \\
\hline 25 & $\mathrm{Fe} / \mathrm{Al}-\mathrm{MCM}-41^{\mathrm{b}}$ & 4 & 97 & 100 & 100 \\
\hline 26 & $\mathrm{Fe} / \mathrm{Al}-\mathrm{MCM}-41^{\mathrm{c}}$ & 0.5 & 64 & 72 & 78 \\
\hline 27 & $\mathrm{Fe} / \mathrm{Al}-\mathrm{MCM}-41^{\mathrm{c}}$ & 1 & 69 & 73 & 77 \\
\hline 28 & $\mathrm{Fe} / \mathrm{Al}-\mathrm{MCM}-41^{\mathrm{c}}$ & 2 & 73 & 78 & 82 \\
\hline 29 & $\mathrm{Fe} / \mathrm{Al}-\mathrm{MCM}-41^{\mathrm{c}}$ & 3 & 76 & 81 & 90 \\
\hline 30 & $\mathrm{Fe} / \mathrm{Al}-\mathrm{MCM}-41^{\mathrm{c}}$ & 4 & 86 & 89 & 93 \\
\hline
\end{tabular}

The products were characterized using ${ }^{1} \mathrm{H}-\mathrm{NMR}$ and GC-MS analysis. Analytical data were in accordance with those reported for authentic samples. Benzylation of toluene and xylene was also carried out at refluxing temperature using benzylchloride and 4-methylbenzylchloride and the results are summarized in Table 3.

Fe/Al-MCM-41 catalysts were found to be highly selective toward the benzylation of substituted benzenes. This study confirms the exclusive and selective formation of para isomers for the benzylation of toluene and xylene using benzylchloride and 4-methylbenzylchloride (Table 3). 1-Benzyl-4-methylbenzene was the product obtained in both the benzylation reactions of toluene with benzyl chloride and benzene with 4-methyl benzyl chloride howeve, higher yield of 1-benzyl-4-methylbenzene was obtained in the former than the latter. This demonstrates the less ability of 4-methylbenzylchloride than 
benzylchloride as an alkylating agent due to the presence of electron donating methyl group. Better yields were obtained when only one $\mathrm{CH}_{3}$ group was present in the substrate with benzylchloride was used as benzylating agent but when two $\mathrm{CH}_{3}$ groups were present in the substrate, the percentage yield was found to be less with both the benzylating agents. This result is opposite to that expected according to the classical mechanism of the Friedel-Crafts acid catalysed benzylation reaction where the benzylation of an aromatic compound is facilitated if one or more electron donating groups are present in the aromatic ring $^{21}$. A similar effect has also been reported on the acetylation of 2-methoxynaphthalene with acetic anhydride over dealuminated HY zeolites ${ }^{22}$.

Table 3. Synthesis of diphenylmethane derivatives over various iron loaded catalysts at reflux condition ${ }^{*}$

\begin{tabular}{|c|c|c|c|c|c|c|}
\hline S.No. & $\mathrm{R}_{1}$ & $\mathrm{R}_{2}$ & $\mathrm{R}_{3}$ & $\mathrm{R}_{4}$ & Catalyst & Total Conversion ${ }^{\mathrm{d}}, \%$ \\
\hline 1 & $\mathrm{H}$ & $\mathrm{H}$ & $\mathrm{H}$ & $p-\mathrm{CH}_{3} \mathrm{C}_{6} \mathrm{H}_{5} \mathrm{CH}_{2-}$ & $\mathrm{Fe} / \mathrm{Al}-\mathrm{MCM}-41^{\mathrm{a}}$ & 85 \\
\hline 2 & $\mathrm{H}$ & $\mathrm{H}$ & $\mathrm{H}$ & $p-\mathrm{CH}_{3} \mathrm{C}_{6} \mathrm{H}_{5} \mathrm{CH}_{2-}$ & $\mathrm{Fe} / \mathrm{Al}-\mathrm{MCM}-41^{\mathrm{b}}$ & 81 \\
\hline 3 & $\mathrm{H}$ & $\mathrm{H}$ & $\mathrm{H}$ & $p-\mathrm{CH}_{3} \mathrm{C}_{6} \mathrm{H}_{5} \mathrm{CH}_{2-}$ & $\mathrm{Fe} / \mathrm{Al}-\mathrm{MCM}-41^{\mathrm{c}}$ & 76 \\
\hline 4 & $\mathrm{CH}_{3}$ & $\mathrm{H}$ & $\mathrm{H}$ & $\mathrm{C}_{6} \mathrm{H}_{5} \mathrm{CH}_{2-}$ & $\mathrm{Fe} / \mathrm{Al}-\mathrm{MCM}-41^{\mathrm{a}}$ & 100 \\
\hline 5 & $\mathrm{CH}_{3}$ & $\mathrm{H}$ & $\mathrm{H}$ & $\mathrm{C}_{6} \mathrm{H}_{5} \mathrm{CH}_{2-}$ & $\mathrm{Fe} / \mathrm{Al}-\mathrm{MCM}-41^{\mathrm{b}}$ & 100 \\
\hline 6 & $\mathrm{CH}_{3}$ & $\mathrm{H}$ & $\mathrm{H}$ & $\mathrm{C}_{6} \mathrm{H}_{5} \mathrm{CH}_{2-}$ & $\mathrm{Fe} / \mathrm{Al}-\mathrm{MCM}-41^{\mathrm{c}}$ & 81 \\
\hline 7 & $\mathrm{CH}_{3}$ & $\mathrm{H}$ & $\mathrm{H}$ & $p-\mathrm{CH}_{3} \mathrm{C}_{6} \mathrm{H}_{5} \mathrm{CH}_{2-}$ & $\mathrm{Fe} / \mathrm{Al}-\mathrm{MCM}-41^{\mathrm{a}}$ & 84 \\
\hline 8 & $\mathrm{CH}_{3}$ & $\mathrm{H}$ & $\mathrm{H}$ & $p-\mathrm{CH}_{3} \mathrm{C}_{6} \mathrm{H}_{5} \mathrm{CH}_{2-}$ & $\mathrm{Fe} / \mathrm{Al}-\mathrm{MCM}-41^{\mathrm{b}}$ & 79 \\
\hline 9 & $\mathrm{CH}_{3}$ & $\mathrm{H}$ & $\mathrm{H}$ & $p-\mathrm{CH}_{3} \mathrm{C}_{6} \mathrm{H}_{5} \mathrm{CH}_{2-}$ & $\mathrm{Fe} / \mathrm{Al}-\mathrm{MCM}-41^{\mathrm{c}}$ & 69 \\
\hline 10 & $\mathrm{CH}_{3}$ & $\mathrm{CH}_{3}$ & $\mathrm{H}$ & $\mathrm{C}_{6} \mathrm{H}_{5} \mathrm{CH}_{2-}$ & $\mathrm{Fe} / \mathrm{Al}-\mathrm{MCM}-41^{\mathrm{a}}$ & 79 \\
\hline 11 & $\mathrm{CH}_{3}$ & $\mathrm{CH}_{3}$ & $\mathrm{H}$ & $\mathrm{C}_{6} \mathrm{H}_{5} \mathrm{CH}_{2-}$ & $\mathrm{Fe} / \mathrm{Al}-\mathrm{MCM}-41^{\mathrm{b}}$ & 65 \\
\hline 12 & $\mathrm{CH}_{3}$ & $\mathrm{CH}_{3}$ & $\mathrm{H}$ & $\mathrm{C}_{6} \mathrm{H}_{5} \mathrm{CH}_{2-}$ & $\mathrm{Fe} / \mathrm{Al}-\mathrm{MCM}-41^{\mathrm{c}}$ & 47 \\
\hline 13 & $\mathrm{CH}_{3}$ & $\mathrm{CH}_{3}$ & $\mathrm{H}$ & $p-\mathrm{CH}_{3} \mathrm{C}_{6} \mathrm{H}_{5} \mathrm{CH}_{2-}$ & $\mathrm{Fe} / \mathrm{Al}-\mathrm{MCM}-41^{\mathrm{a}}$ & 57 \\
\hline 14 & $\mathrm{CH}_{3}$ & $\mathrm{CH}_{3}$ & $\mathrm{H}$ & $p-\mathrm{CH}_{3} \mathrm{C}_{6} \mathrm{H}_{5} \mathrm{CH}_{2^{-}}$ & $\mathrm{Fe} / \mathrm{Al}-\mathrm{MCM}-41^{\mathrm{b}}$ & 50 \\
\hline 15 & $\mathrm{CH}_{3}$ & $\mathrm{CH}_{3}$ & $\mathrm{H}$ & $p-\mathrm{CH}_{3} \mathrm{C}_{6} \mathrm{H}_{5} \mathrm{CH}_{2-}$ & $\mathrm{Fe} / \mathrm{Al}-\mathrm{MCM}-41^{\mathrm{c}}$ & 36 \\
\hline
\end{tabular}

${ }^{*}$ Reaction conditions: Catalyst $=0.1 \mathrm{~g}$; reaction time $=4 \mathrm{~h}^{\mathrm{a}} \mathrm{Si} / \mathrm{Al}=25^{\mathrm{b}} \mathrm{Si} / \mathrm{Al}=50^{\mathrm{c}} \mathrm{Si} / \mathrm{Al}=100$

${ }^{d}\left(\mathrm{C}_{6} \mathrm{H}_{5} \mathrm{CH}_{2}\right)_{2} \mathrm{CH}_{2}$ isomers, exclusive $100 \%$ selectivity of para isomers in each case

\section{Catalyst reusability}

The catalyst was separated from the reaction using simple filtration technique, washed with acetone, air dried and used for subsequent two runs of the reaction process. The results were consistent for all the consequent runs

\section{Conclusions}

Thus, iron loaded MCM-41 catalysts can be used as efficient catalysts for the synthesis of benzyl aromatics and therefore Fe/Al-MCM-41 could be a convenient substitute for hazardous FriedelCrafts catalysts like $\mathrm{FeCl}_{3}$ and $\mathrm{AlCl}_{3}$. The Fe/Al-MCM-41 catalysts are recyclable, heterogeneous, environmentally benign solid acid catalysts possessing desirable properties such as high thermal and hydrothermal stability which are the prerequisite in the area of green chemistry. This study provides a green and selective route for the alkylation of aromatics.

\section{References}

1 Kresge C T, Leonowicz M E, Roth W J, Vartulli J C and Beck J S, Nature, 1992, 359, 710-712. 
Corma A, Chem. Rev. 1997, 97, 2373.

3 Beck J S, Vartulli J C, Roth W J, Leonowicz M E, Kresge C T, Schmitt K D, Chu C T W, Olson D H, Sheppard E W, McCullen S B, Higgins J B and Schlenker J L, J. Am. Chem. Soc. 1992, 114, 10834.

4 Corma A, Grande M S, Gonzalez A V and Orchilles A V, J. Catal. 1996, 159, 375.

5 Devendrapratap U S and Samant D S, J. Mol. Catal. A: Chem. 2004, 223, 111.

6 Hagen A, Schneider E, Benter M, Krogh A, Kleinert A and Roessner F, $J$. Catal. 2004, 226, 171.

$7 \quad$ Choudhary V R, Jana S K and Kiran B P, Catal. Lett. 2004, 59, 217.

8 Sabu K R, Sukumar R, Rekha R and Lalithambika M A, Catal. Today, 1999, 49, 321.

$9 \quad \mathrm{Hu}$ X, Chuah G K and Jaenicke S, Appl. Catal. A: Gen. 2001, 217, 1.

10 Silva M S M, Costa C L, Pinto M M and Lachter E R, Reactive Polymers, 1995, 25, 55.

11 Yamashita K, Hirano M, Okumura K and Niwa M, Catal. Today, 2006, 118, 385.

12 Choudary B M, Sreenivasa C N, Lakshmi K M and Kannan R, Tetrahedron Letters, 1999, 40, 2859.

13 He N, Bao S and Xu Q, Appl. Catal. A: Gen. 1998, 169, 29.

14 Bachari K, Millet J M M, Bonville P, Clerifi O and Figueras F, J. Catal. 2007, 249, 52.

15 Vinu A, Sawant D P, Ariga K, Hossain K Z, Halligudi S B, Hartmann M and Nomura M, Chem. Mater. 2005, 17, 5339.

16 Decyk P, Trejda M and Ziolek M, C. R. Chimie: Chem. 2005, 8, 635.

17 Trejda M, Kujawa J and Ziolek M, Catal. Lett. 2006, 108, 141.

18 Olah G A, in: Friedel-Crafts and Related Reactions (Wiley-Interscience, New York), 1963.

19 Revathi S, Esther Leena Preethi M, Siddarth S and Sivakumar T, Catal. Commun. 2007, 8, 2043.

20 Esther Leena Preethi M, Revathi S, Sivakumar T, Manikandan D, Ivakar D, Valentine Rupa A, Palanichami M, Catal. Lett. 2008,120,56.

21 Choudhary V R, Jana S K and Kiran B P, J. Catal. 2000, 192, 257.

22 Merie P, Finicis A and Moreau P, J. Mol. Catal. A: Chem. 2002,189, 251 


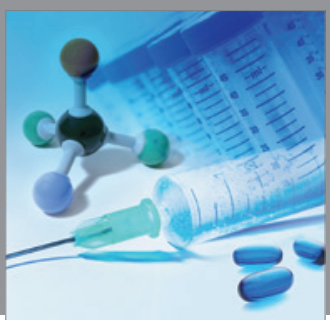

International Journal of

Medicinal Chemistry

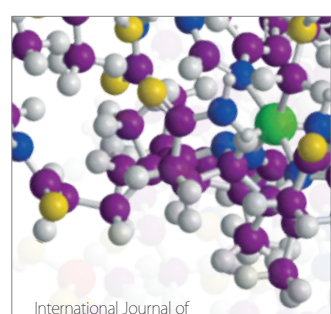

Carbohydrate Chemistry

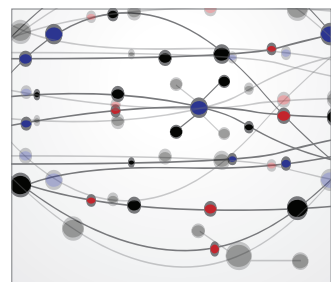

The Scientific World Journal
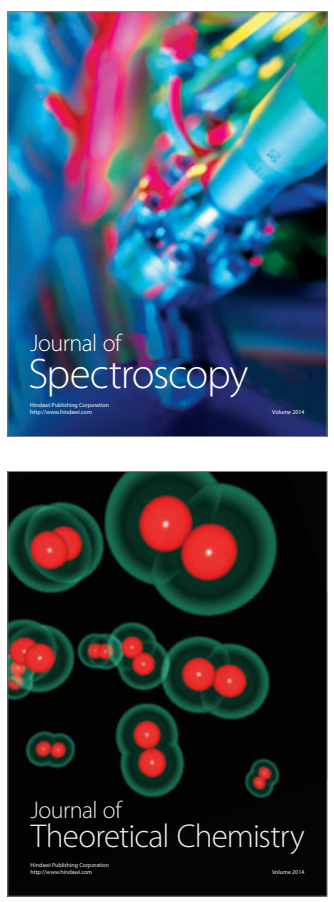
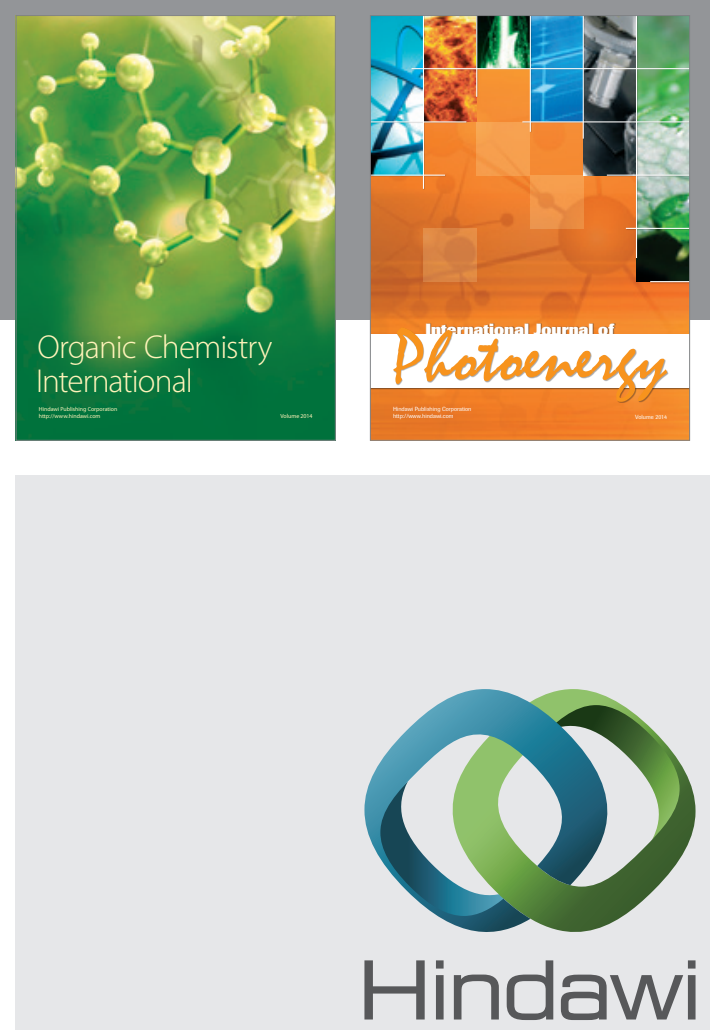

Submit your manuscripts at

http://www.hindawi.com
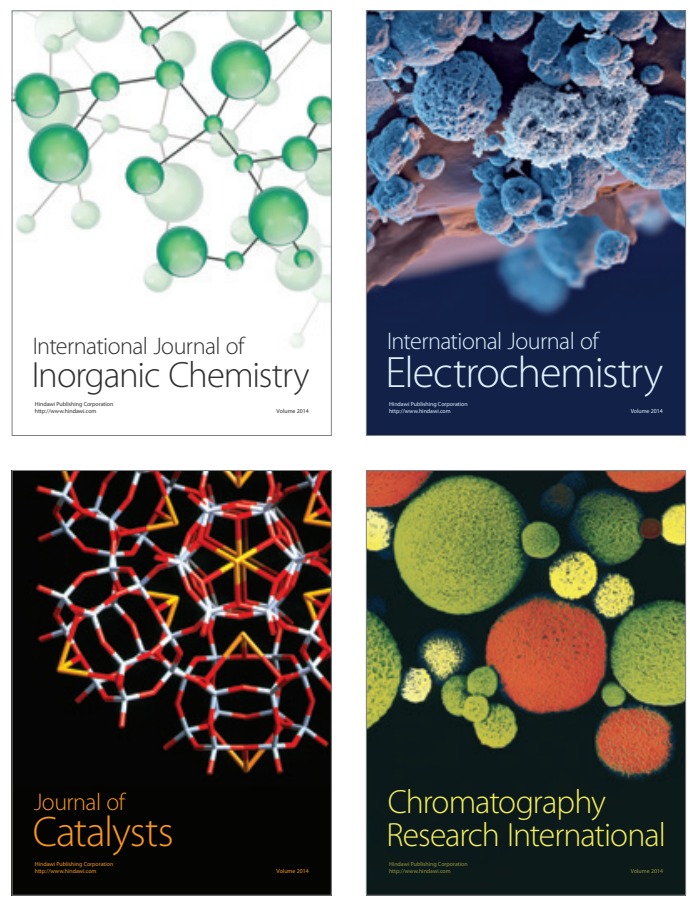
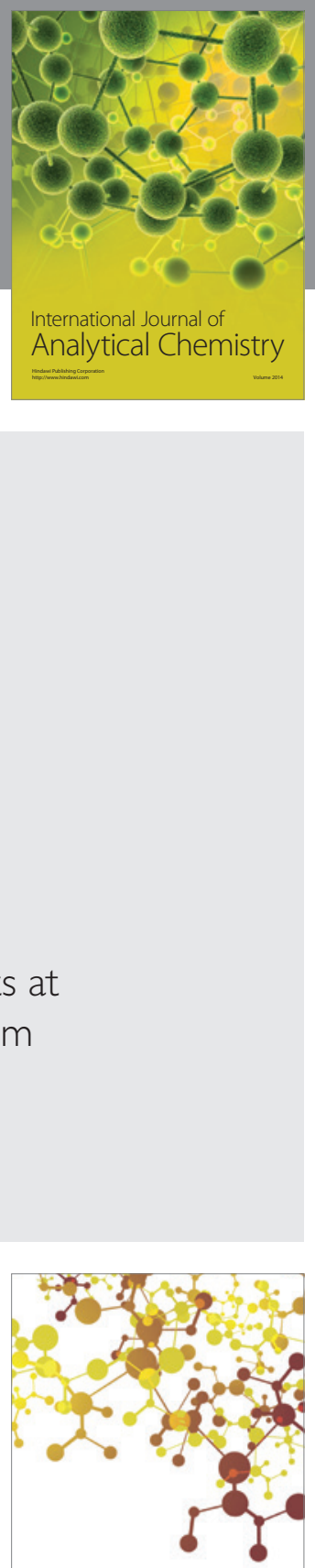

Journal of

Applied Chemistry
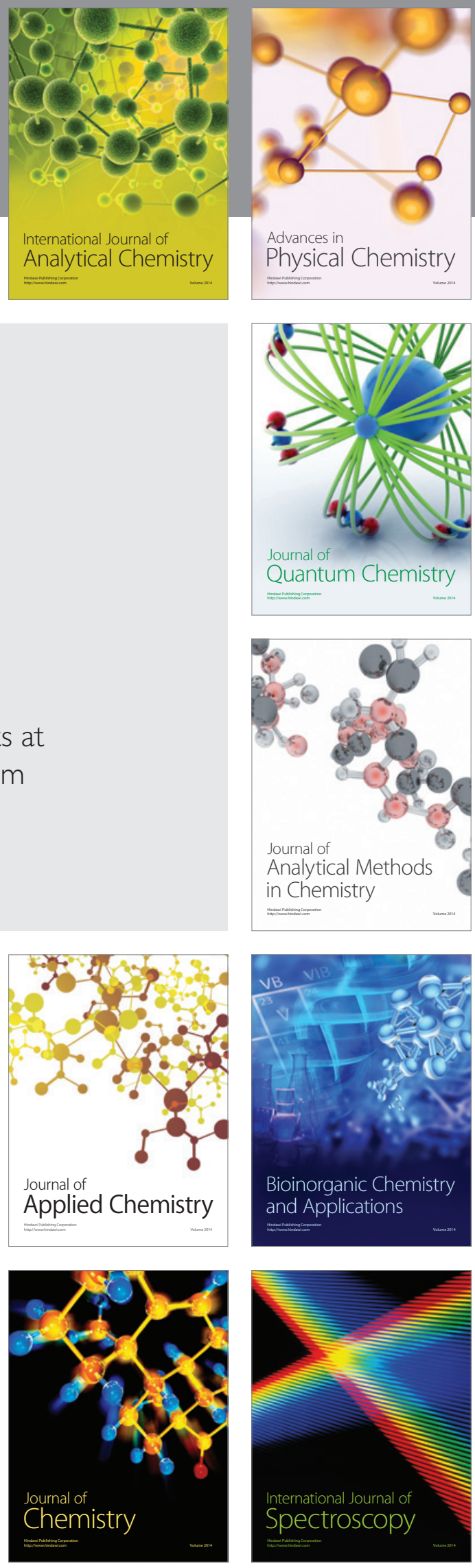